\title{
IMPACT OF THE THICKNESS OF THE WALL OF OPTICAL LENSES ON THE PRODUCTION PROCESS STABILITY
}

\author{
Martin Šinkora $^{l}$, PhD, Miroslav Žitnák ${ }^{l}$, PhD, Maroš Korenko ${ }^{1}$, PhD, \\ Taras Shchur ${ }^{2}$, PhD, Olexandr Pushka ${ }^{3}$, PhD, Yuriy Gabriel ${ }^{2}$, engineer

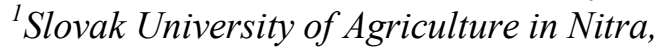 \\ Trieda Andreja Hlinku 2, 94976 Nitra-Chrenová, Slovakia \\ ${ }^{2}$ Lviv National Agrarian University, \\ 1 Volodymyra Velykoho Str., Dubliany-Lviv, Ukraine, \\ e-mail:shchurtg@gmail.com \\ ${ }^{3}$ Uman National University of Horticulture, \\ 1, Instytutska str., Uman, Ukraine
}

https://doi.org/10.31734/agroengineering2021.25.083

\begin{abstract}
Šinkora M., Žitnák M., Korenko M., Shchur T., Pushka O., Gabriel Yu. Impact of the thickness of the wall of optical lenses on the production process stability

The article compares the stability of the production process of plastic optical lenses produced by the injection molding process. Moreover, it evaluates the effects caused by using very thick walls and very thin walls in plastic optical lenses. The injection process are divided into three fundamental stages. The first is the injection of plastic into the mold itself (filling). During this phase, $95-99 \%$ of the cavity volume is filled. The second phase is the so-called after-pressure, where the remaining cavity spaces are filled, and the part reaches dimensional stability. The last stage is called cooling. During the final phase, the element is solidified and becomes dimensionally stable in lower temperatures. In the current work, the authors compare the lenses that differ only in the maximum wall thickness. In the experiments, the conditions of changing pressure and injection speed were simulated. During injection, slight changes in the injection parameters may occur due to the random external influences. Those influences include the change in ambient air temperature, voltage fluctuations in the electrical system, machine vibrations, imperfect homogeneity of the material used, etc. The common process parameters that the organization uses by default were used as a basis. The after-pressure and injection pressure were changed to $102 \%$, $105 \%, 98 \%$, and $95 \%$ in the experiments. The results evaluate the proportion of non-conforming products (scrap) that appertain to each change in the parameters of production.

The research proves the dependence between the thickness of the lens wall and the stability of the process. Although a higher total waste is expected for thick-walled lenses, the knowledge of the stability of the process in the production of lenses has not yet been recorded though it is a significant indicator for the production planning. It is known that a lower process stability is expected based on the design for these types of elements, and the researrchers were able to take measures to eliminate this risk and thus reduce the total waste and other negative impacts on production.

Modifications to the mold can also achieve some improvement in this condition. The first step is to expand the cross-section of the inlet channel gate. The pressure is transmitted to the cavity through this cross-section. Its enlargement ensures a more even distribution of the pressure in the entire volume of the part. Another way to facilitate production is to guarantee optimal cooling of the cavity. It can be achieved by placing the cavity away from the hot runner system so that the cooling can be evenly distributed around each side of the part. The last way to solve the problem of collapse is to create a counterdeformation in the mold. That is to enlarge the cavity so that the lens sinks into the desired shape.

These measures may include preventive debugging of the mold for multiple presses in case the press needs to be changed and preferably placing such elements on newer injection molding machines where parameters are less likely to fluctuate and avoiding moving such molds to presses for which they have not been debugged unless necessary. The work aims to prove the dependence between the thickness of the optical lens and the stability of the injection process. While waste percentage, cycle time, and other parameters are considered and quantified at the design stage of the optical lens, process stability has not yet been quantified. Proving the dependence between the above-mentioned phenomena will allow predicting the process stability of new lens designs more precisely.
\end{abstract}

Key words: process stability, optical lense, injection molding, product quality.

Сінкора М., Житняк М., Коренко М., Щур Т., Пушка О., Габрісль Ю. Вплив товщини стінки оптичних лінз на стабільність виробничого процесу

У статті порівнюється стабільність процесу виробництва пластикових оптичних лінз, виготовлених методом лиття під тиском. Крім того, вона оцінює ефекти, викликані використанням дуже товстих і дуже тонких стінок у пластикових оптичних лінзах. Ми поділясмо сам процес ін'єкційного лиття на три основні етапи. Перший - це вливання пластику в саму форму (наповнення). Під час цієї фази заповнюється $95-99$ \% об’єму порожнини. Другою фазою $є$ так званий посттиск, при якому заповнюється решта порожнини і деталь досягає стабільності розмірів. Останній етап називається охолодженням. Під час останньої фази елемент застигає і стає розмірно стабільним при 
нижчих температурах. У своїй роботі ми порівнювали лінзи, які відрізнялися лише максимальною товщиною стінки. У дослідах моделювали умови зміни тиску та швидкості нагнітання. Під час ін'єкційного лиття можуть відбутися незначні зміни параметрів ін'єкції через випадкові зовнішні впливи. Ці впливи включають зміну температури навколишнього середовища, коливання напруги в електричній системі, вібрації машини, неповну однорідність використовуваного матеріалу тощо. За основу були використані загальні параметри процесу, які організація використовує за замовчуванням. В експериментах ми змінювали посттиск і тиск упорскування на $102 \%, 105 \%, 98$ \% і 95 \%. За результатами оцінюється частка бракованої продукції (брухту), що з'являлася після кожної зміни параметрів виробництва.

Можна сказати, що нам вдалося довести зв'язок між товщиною стінки лінзи і стабільністю процесу. Хоча для товстостінних лінз очікується більший загальний обсяг відходів, знання про стабільність процесу у виробництві лінз ще не зафіксовано, незважаючи на те, що це $\epsilon$ важливим показником для планування виробництва. Знаючи, що ми можемо очікувати нижчої стабільності процесу на основі конструкції для цих типів елементів, ми можемо вжити заходів, щоб усунути цей ризик і таким чином зменшити загальну кількість браку та інші негативні впливи на виробництво.

Модифікації форми також можуть досягти певного поліпшення цього стану. Першим кроком $є$ розширення поперечного перерізу затвора вхідного каналу. Через цей поперечний переріз в порожнину передається тиск. Його збільшення забезпечує більш рівномірний розподіл тиску у всьому об'ємі деталі. Інший спосіб полегшити виробництво - гарантувати оптимальне охолодження порожнини. Ми можемо досягти цього, розташувавши порожнину подалі від системи гарячих каналів, щоб охолодження могло бути рівномірно розподілене по кожній стороні деталі. Останній спосіб вирішити проблему руйнування - створити зустрічну деформацію в кристалізаторі, тобто розширити порожнину, щоб лінза опустилася в потрібну форму.

Ці заходи можуть передбачати превентивне налагодження прес-форми для декількох пресів у разі, якщо прес потрібно змінити, і бажано розміщення таких елементів на новіших машинах для лиття під тиском, де параметри менш схильні до коливань, і уникнення переміщення таких форм до пресів, для яких вони не були призначені. Метою роботи $є$ доведення залежності між товщиною оптичної лінзи та стабільністю процесу лиття. Хоча відсоток відходів, час циклу та інші параметри враховуються та визначаються кількісно на етапі проєктування оптичної лінзи, стабільність процесу ще не визначена кількісно. Якщо ми доведемо залежності між вищезгаданими явищами, це дозволить точніше спрогнозувати стабільність процесу нових конструкцій лінз.

Ключові слова: стабільність процесу, оптична лінза, лиття під тиском, якість продукції.

Introduction. A high-pressure injection is standardly defined as "a method of forming plastic elements by heating the molding material to make it flowable and then injecting it into a mold" $[5 ; 6 ; 16]$. The injection process are divided into three fundamental stages. The first is the injection of plastic into the mold itself (filling). During this phase, 95$99 \%$ of the cavity volume is filled. The second phase is the so-called after-pressure, where the remaining cavity spaces are filled, and the part reaches dimensional stability. The last stage is called cooling. During the final phase, the element is solidified and becomes dimensionally stable in lower temperatures.

A necessary condition for quality production is that the machine, in combination with the mold, can produce identical consecutive parts at set parameters. During injection, slight changes in injection parameters may occur due to the random external influences. These influences include the change in ambient air temperature, voltage fluctuations in the electrical system, machine vibrations, imperfect homogeneity of the material used, and the like.

Process stability is the ability of a machine and a mold to produce identical parts in a row under the influence of random external impacts. This stability can be tested by intentionally changing some process parameters (such as material temperature or injection pressure) by small values and monitoring whether we can still produce identical parts. If so, the process is stable even if the parameters change randomly by some percentage value (most often $2 \%, 5 \%$, and so forth). The range of process parameters at which the machine can produce suitable parts is called the process window $[12 ; 13 ; 14]$.

Optical lenses are used in automotive applications in combination with12 LED bulbs. An LED bulb, or more commonly a set of bulbs, acts as a light source. The optical lens then collects the light produced by these LEDs and changes its direction to achieve the desired light distribution [1]. We achieve these properties by using a specific lens geometry. The side from which the light enters must be straight and smooth, while the side from which the light concentrates and where it emits has the shape of a spherical lens.

The desired curvature and size of the lens itself (height and width) then results in the determined lens thickness. From the point of view of the production of plastic parts, this shape requirement is the main complication due to the manufacturing errors known as sink marks and bubble formation. When designing plastic parts, we try to avoid excessive concentrations of material. On the contrary, when designing optical lenses, the concentration of material is necessary [2; $7 ; 8 ; 11 ; 15]$ 
There are several ways to solve this problem. All of them are commonly applied simultaneously. They support each other in their benefits but unfortunately also in their negatives. From the injection moulding process point of view, sinking material can be solved by prolonging the afterpressure time and the cooling time. The reason is to ensure the consolidation of dimensions during the after-pressure. Subsequently, a gradual equalization of temperatures in the total volume of the lens is achieved by extended cooling. Otherwise, deformations would occur after removing the part from the mould.

Modifications to the mould can also achieve some improvement in this condition. The first step is to expand the cross-section of the inlet channel gate. The pressure is transmitted to the cavity through this cross-section. Its enlargement ensures a more even distribution of the pressure in the entire volume of the part. Another way to facilitate production is to guarantee optimal cooling of the cavity. It can be achieved by placing the cavity away from the hot runner system so that the cooling can be evenly distributed around each side of the part. The last way to solve the problem of collapse is to create a counterdeformation in the mould. That is to enlarge the cavity so that the lens sinks into the desired shape.

The work aims to prove the dependence between the thickness of the optical lens and the stability of the injection process.

While waste percentage, cycle time, and other parameters are considered and quantified at the design stage of the optical lens, process stability has not yet been quantified. Confirmong the dependence between the above-mentioned phenomena will allow predicting the process stability of new lens designs more precisely.

Material and methods. The selection process of the monitored parts was realized according to the task. When choosing lenses, the task was to find ones that will be as identical as possible in all properties except wall thickness. Subsequently, the measurements that simulated random fluctuations in the specified process parameters and compared how the share of non-conforming products in total production changes based on these changes were performed.

The selected lenses were marked as "lens A" thick-walled lens and "lens B" - thin-walled lens. Both are made of PMMA type material, specific trade name: Plexi 8N SuPure clear. Lenses A and B have the characteristics listed in Table 1.

Experimental conditions. The first condition in an experiment examining stability and the process window was to ensure that the process ran as it standardly does before it was subjected to an experiment. In the case of both lenses, it was determined whether it was normal production based on long-term observation of the share of nonconforming products in the total production. If the observed percentage of non-conforming products was close to the long-term average of non-conforming products before the start of the experiment, one could say that the process was running normally.

The mould for the production of lenses A has been producing lenses since the beginning of 2021 on the injection moulding machine No. 49 (Engel victory $80 \mathrm{~T}$ ) a total of five times. Table 2 shows the production process and the proportion of nonconforming products in individual productions.

In the reseaecrh, a $50 \%$ mean interval was used to determine the range of non-conforming products at which the production standardly occurs. The value of the interval is 2.495 , which implied that if the share of waste in the production was in the range from $2.503 \%$ to $7.493 \%$, that production couls be considered as normal.

The mould for the production of lenses B has been producing lenses from the beginning of 2021 on the injection moulding machine No. 53 (Engel victory 50T) four times in total. Table 3 displays the course of production and the share of non-conforming products in individual productions.

Table 1. Properties of selected optical lenses A and B

Таблиця 1. Властивості вибраних оптичних лінз А і В

\begin{tabular}{|l|l|l|l|l|l|l|l|l|}
\hline & $\begin{array}{l}\text { Surface } \\
\text { area, } \mathrm{cm}^{2}\end{array}$ & $\begin{array}{l}\text { Volume, } \\
\mathrm{cm}^{3}\end{array}$ & $\begin{array}{l}\text { Surface } \\
\text { treatment }\end{array}$ & $\begin{array}{l}\text { Use in the } \\
\text { light }\end{array}$ & $\begin{array}{l}\text { The } \\
\text { inlet } \\
\text { type }\end{array}$ & $\begin{array}{l}\text { Number of } \\
\text { cavities in } \\
\text { the form }\end{array}$ & $\begin{array}{l}\text { Used } \\
\text { injection } \\
\text { molding } \\
\text { machine }\end{array}$ & $\begin{array}{l}\text { The } \\
\text { largest } \\
\text { wall } \\
\text { thickness, } \\
\text { mm }\end{array}$ \\
\hline A & 36,6 & 6.2 & High Gloss & $\begin{array}{l}\text { High Beam } \\
\text { Lens }\end{array}$ & Film & 4 & $\begin{array}{l}\text { Engel } \\
\text { victory 80t }\end{array}$ & 12.39 \\
\hline B & 37,5 & 4.8 & High Gloss & $\begin{array}{l}\text { High Beam } \\
\text { Lens }\end{array}$ & Film & 4 & $\begin{array}{l}\text { Engel } \\
\text { victory 50t }\end{array}$ & 3.88 \\
\hline
\end{tabular}


Table 2. Production of lenses A from the beginning of 2021

Таблиця 2. Виробництво лінз А з початку 2021 року

\begin{tabular}{|l|l|l|l|l|l|l|}
\hline Production number & 1 & 2 & 3 & 4 & 5 & Total \\
\hline Date & $9-14.01$ & $21-25.01$ & $29-03.02$ & $16-18.02$ & $1 .-10.03$ & 26793 \\
\hline $\begin{array}{l}\text { Number of pieces } \\
\text { produced }\end{array}$ & 7000 & 2720 & 5556 & 4108 & 7409 & 1339 \\
\hline $\begin{array}{l}\text { Non-conforming } \\
\text { products, pcs }\end{array}$ & 356 & 128 & 96 & 276 & 483 & 4.998 \\
\hline $\begin{array}{l}\text { Non-conforming } \\
\text { products, \% }\end{array}$ & 5.086 & 4.706 & 1.728 & 6.719 & 6.519 & \\
\hline
\end{tabular}

Table 3. Production of lenses B from the beginning of 2021

Таблиця 3. Виробництво лінз Б з початку 2021 року

\begin{tabular}{|l|l|l|l|l|l|}
\hline Production number & 1 & 2 & 4 & 5 & Total \\
\hline Date & $13-16.01$ & $24-28.01$ & $12-15.02$ & $1-8.03$ & \\
\hline Number of pieces produced & 4867 & 5209 & 3600 & 10500 & 24176 \\
\hline $\begin{array}{l}\text { Non-conforming products, } \\
\text { pss }\end{array}$ & 74 & 103 & 41 & 188 & 406 \\
\hline $\begin{array}{l}\text { Non-conforming products, } \\
\%\end{array}$ & 1.520 & 1.977 & 1.139 & 1.790 & 1.679 \\
\hline
\end{tabular}

The same mean interval was applied. It will have a value of $0.419 \%$ for lens B. That denotes that if the share of waste in production is in the range of $1.260 \%$ to $2.098 \%$, that production could be considered as normal.

To determine the stability of the process and compare the results, four identical interventions were performed in the process for both lenses. In the Experiment 1, the after-pressure and injection pressure were set to $102 \%$ of the value specified in the mould datasheet. In the Experiment 2, those values were set up to $105 \%$. In the Experiment 3, the values were set in the opposite direction to $98 \%$. to $95 \%$.

In the last experiment 4 , both values were set

During each experiment, 10 sets of lenses were made. Both molds for lens A and B have four cavities. Hence, 40 parts were taken to evaluate one experiment. The parts were evaluated visually.

Results and discussion. Lens A experiments. Lens A experiments took place on the $13^{\text {th }}$ of March from 11:00 to 13:45. From the start of the shift at 6:00, the injection molding machine produced 72 sets of optical lenses (288 pieces). Fifteen of these were unsatisfactory. There were $5.208 \%$ of nonconforming products, which at intervals implies normal production. All experiments were performed without interrupting production. The results are captured in the Table 4.

In the first experiment, with an after-pressure and injection pressure of $102 \%$, only one piece of the lens was observed, and it was marked as a nonconforming product. Figure 1 presents a line passing through the middle part of the slide. The nonconforming product came from cavity number 2 .

In the second experiment with the values of $105 \%$, substantial errors were marked on the entire surface of the produced lenses. Although the increased pressure did not change the dimensional properties of the part, it resulted in formation of additional scratches and creep marks on the surface of the produced lenses. Six of these scratches were very similar to those shown in the Figure 1. Another seven parts were marked as non-conforming products due to scratches in the lens area. That is illustrated in the Figure 2. Figure 3 pictures a combination of scratches and creep marks. It was noticed in four cases.

Table 4. Results of optical lens A experiments

Таблиця 4. Результати експериментів з оптичною лінзою А

\begin{tabular}{|c|c|c|c|c|}
\hline Experiment number & $\begin{array}{c}1 \\
(102 \%)\end{array}$ & $\begin{array}{c}2 \\
(105 \%)\end{array}$ & $\begin{array}{c}3 \\
(98 \%)\end{array}$ & $\begin{array}{c}4 \\
(95 \%)\end{array}$ \\
\hline Number of pieces produced & 40 & 40 & 40 & 40 \\
\hline Non-conforming products, $p c s$ & 1 & 17 & 4 & 11 \\
\hline Non-conforming products, $\%$ & 2.5 & 42.5 & 10 & 27.5 \\
\hline
\end{tabular}




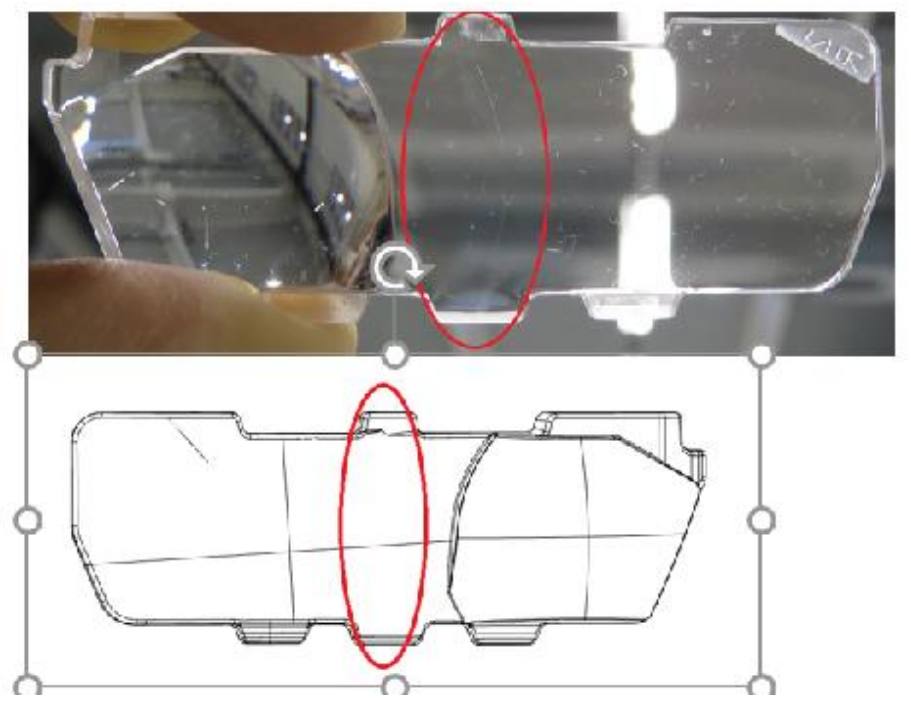

Fig. 1. Scratch in the middle of the slide Рис. 1. Подряпина в середині слайда

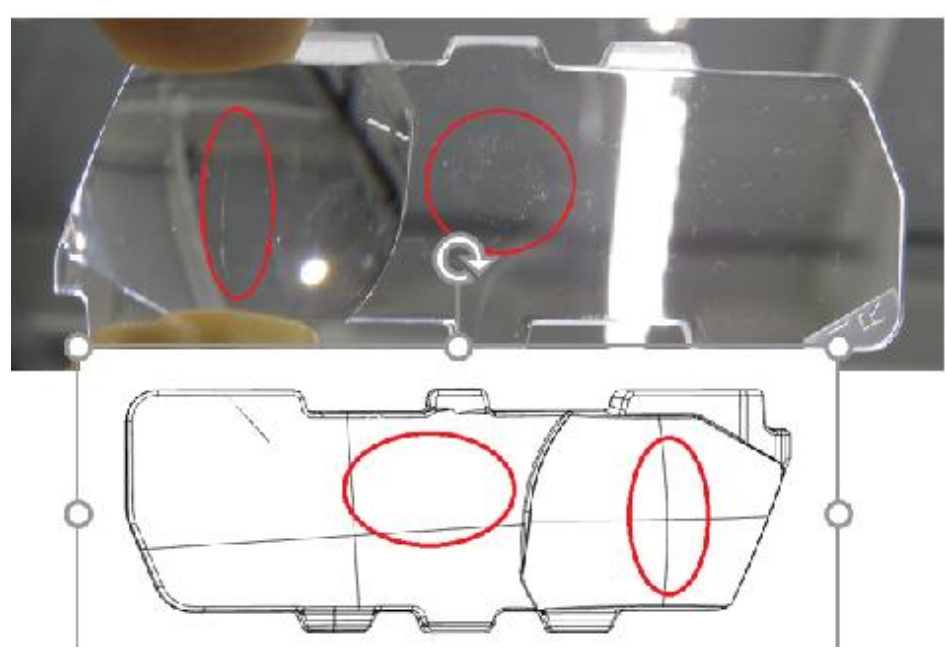

Fig. 2. Scratch in the lens area

Рис. 2. Подряпина в області лінзи

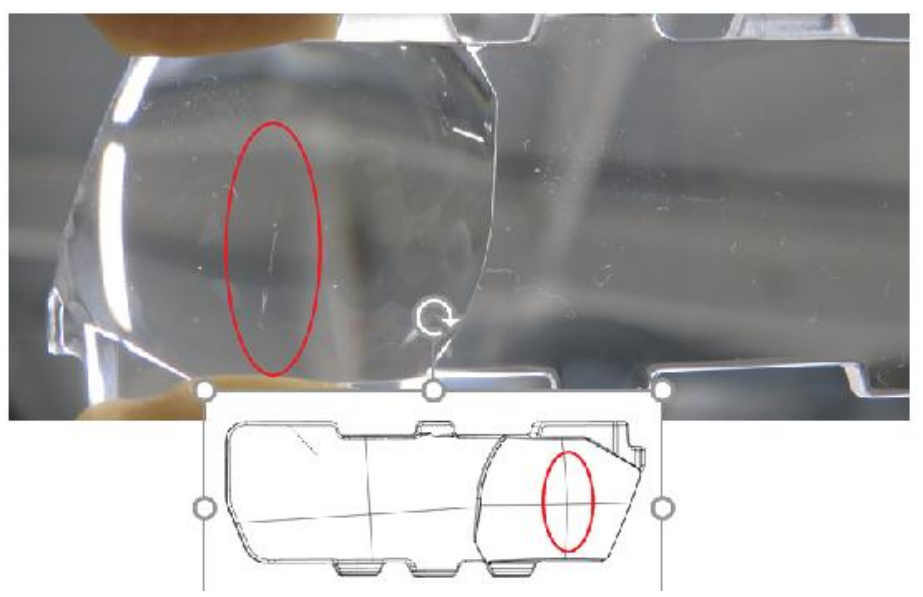

Fig. 3. Scratch in the lens area and creep in the slide area Рис. 3. Подряпини в області лінз і повзучості в області слайда 


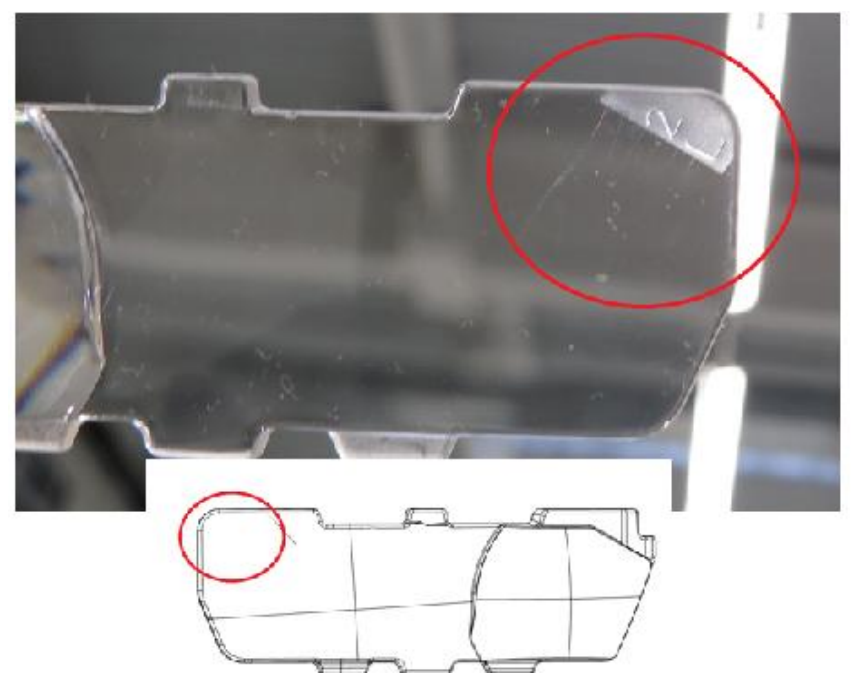

Fig. 4. Scratches in the upper right corner of the slide

Рис. 4. Подряпини в правому верхньому куті слайда

Cavity number 2 in the mold was most affected by the change in pressure. During the experiment 2 , all lenses produced by it showed the scratches shown in Figures 1 and 2. Other non-conforming products were formed relatively evenly in the other cavities. The distribution of non-conforming products in the cavities was $\mathrm{K} 1=3, \mathrm{~K} 2=10, \mathrm{~K} 3=2, \mathrm{~K} 4=2$.

In the third experiment, two identical scratches and creep marks were observed as in the Figure 3. Both are manifested in Cavity 3. In Cavity 2, no scratch was observed in Experiment 2. However, two scratches of the type, shown at the Figure 4, appeared.

In the last experiment, one scratch of Figure 4 appeared in the cavity number 2 . However, a new problem has arisen with sink marks in the lens area. The sink marks are captured at the Figure 5. Due to the great difficulty of photographing the sink marks of a transparent part, the error in the image is not very visible. The distribution of sink marks in the cavities was $\mathrm{K} 1=4, \mathrm{~K} 2=2, \mathrm{~K} 3=4, \mathrm{~K} 4=2$.

After the end of the experiments, the mould continued production during the next shift with the setting of nominal parameters at the level of $100 \%$. By the end of the shift, the number of non-conforming products had reached $4.860 \%$.
Lens B experiments. Lens B experiments took place on 26.03 from 9:00 to 10:15. From the start of the shift at 6:00, the injection moulding machine produced 55 sets of optical lenses, which means 220 pieces. Seven pieces of these were unsatisfactory. Non-conforming products were at the level of $1.272 \%$, which was in the interval indicating normal production. All experiments were performed without interrupting production. The results are pictured in the Table 6.

In the first experiment, one piece with a scratch appeared in the corner of the lens 1 of cavity 1 was observed.

In the second experiment, the number of defects in the corner increased. All occurred on cavity 1 in the lower-left corner. In all these cases, it was a variant of the scratch shown in the Fig. 6.

In the third experiment, no lens with defects were noticed.

In the fourth experiment, one lens with a defect was recorded. Initially, it was not noticed, and was only discovered during the transillumination test. The only way to photograph it was against a window, as seen in Figure 7. This part came from cavity 4.

Table 5. Results of experiments on the optical lens B

Таблиця 5. Результати дослідів на оптичній лінзі В

\begin{tabular}{|c|c|c|c|c|}
\hline Experiment number & $\begin{array}{c}1 \\
(102 \%)\end{array}$ & $\begin{array}{c}2 \\
(105 \%)\end{array}$ & $\begin{array}{c}3 \\
(98 \%)\end{array}$ & $\begin{array}{c}4 \\
(95 \%)\end{array}$ \\
\hline Number of pieces produced & 40 & 40 & 40 & 40 \\
\hline Non-conforming products, pcs & 1 & 4 & 0 & 1 \\
\hline Non-conforming products, $\%$ & 2.5 & 10 & 0 & 2.5 \\
\hline
\end{tabular}




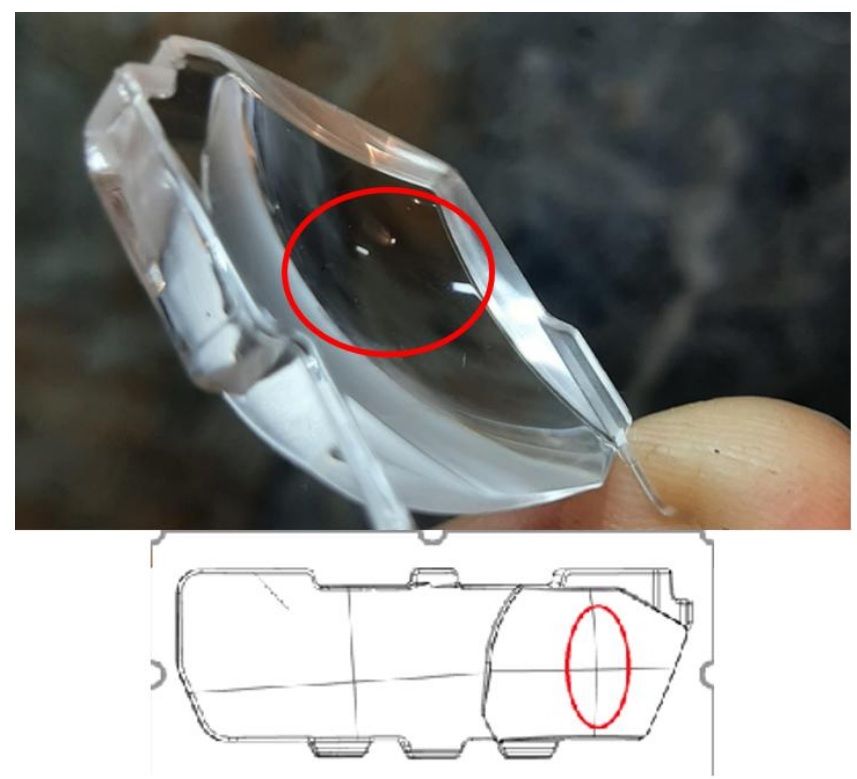

Fig. 5. Depression in the lens area

Рис. 5. Заглиблення в області лінзи

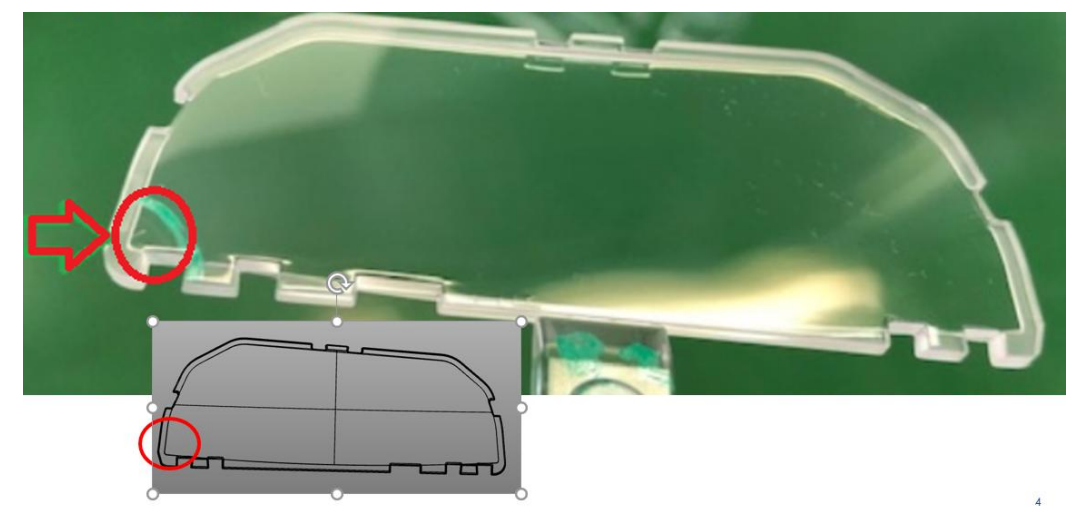

Fig. 6. Scratch in the corner of the part in the cavity 1

Рис. 6. Подряпина в кутку деталі в порожнині 1

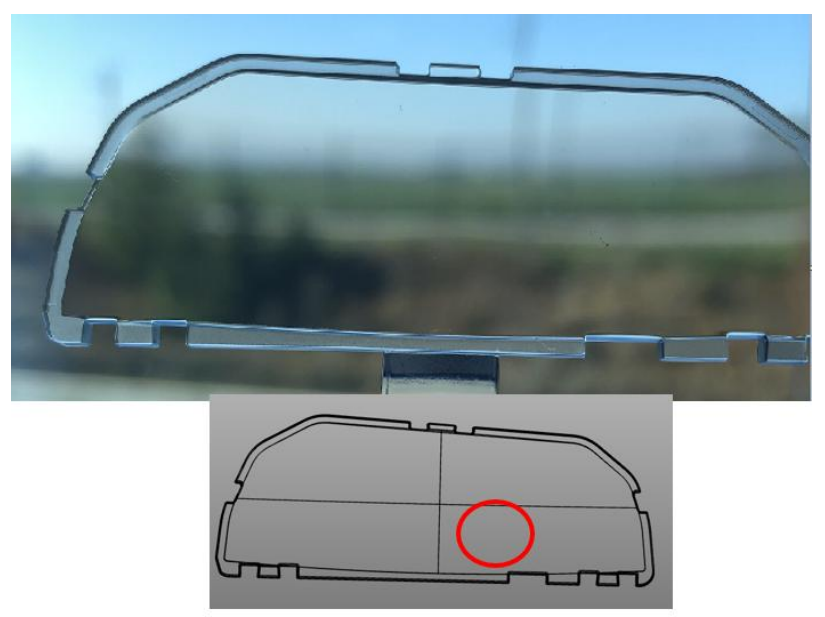

Fig. 7. Scratch the centre of the lens

Рис. 7. Подряпина в центрі лінзи 
Most scratches occurred at the edges of the lenses, where the greater wall thickness changed to a smaller one. That is because, during the process of filling the cavity with material, these edge areas tend to be filled last. For the material to reach these areas, it is under increasing pressure. The scratch is then due to the material being pressed too hard against the steel. In the case of scratches in the edge areas close to the parting plane, these are demolding scratches, where the edge of the parting plane scratches the parts during demolding $[4 ; 9 ; 10]$. In the case of scratches in the middle of the lens, this is a similar principle, where the lens is scratched as a result of "sticking" to the cavity.

The second observed phenomenon was an increased incidence of defects in certain cavities compared to others. In the case of lens $\mathrm{A}$, it was cavity 2 . In the case of lens B, five of the six scratches were observed in cavity 1 . That may be due to uneven material distribution. The inlet channel is usually centred so that the flow of material from the nozzle is distributed evenly among all cavities. However, due to inaccuracies in production, it is practically impossible to tune it so that the distribution is perfectly accurate. Such inaccuracies lead to instability of the laminar flow of plastic in the switchboard [3; 17]. Therefore, one cavity is always filled a little earlier than the others. If it is possible to adjust the process by adjusting the injection parameters so that the total waste is not high, that is fine. However, such inaccuracies contribute to lowered process stability.

Conclusion. The work aimed to compare the stability of the process for two types of optical lenses, depending on their thickness.

A large part of the scratches and optical defects occurred in lens $\mathrm{A}$ in the side area, outside the zone with the greatest wall thickness. We assumed that this was due to the steep transition in wall thickness between the two zones. That resulted in the pressure acting through the lens on the already solidified wall of the side and forming cracks. In cavity, where the most substantial number of errors occurred, there may also be a problem with unbalanced filling. If the first is filled, the injection pressure here will cause a higher material flow rate than in other cavities, resulting in traces of creep. Of course, one can expect these defects in the design of this lens. The normal waste of this lens is also greater than with thin-walled lenses.

In the case of optical lens B, a greater process stability was confirmed. The total value of nonconforming products during the four experiments reached $3.75 \%$, which is only slightly higher than the normal waste on this lens. There was also a problem with unbalanced filling, with five of the six nonconforming products coming from cavity 1 of this mold. Due to the better design of this lens in terms of material injection, the shape of this lens was able to produce in a more stable process as compared to lens A.

The authors of the research managed to prove the connection between the thickness of the lens wall and the stability of the process. Although, a higher total waste is expected for thick-walled lenses, knowledge of the stability of the process in the production of lenses has not yet been accumulated. At the same time, they are a significant indicator for production planning. Expecting a lower process stability based on the design for these types of lens, one can take measures to eliminate this risk and thus, to reduce the total waste and other negative impacts on production.

These measures may include preventive tuning of the mold for multiple IMM machines in case the injection machine needs to be changed. Preferably placing such lenses on newer injection molding machines where parameters are less likely to fluctuate and avoiding moving such molds to injection machines for which they have not been tuning unless necessary.

In further investigating the stability of the process, it would be the best course of action to perform similar experiments on several pairs of lenses and quantify from this database how much the stability of the process decreases as the maximum wall thickness increases. This parameter could be included in the lens cost calculation phase.

\section{References}

1. Aure-Lighting. 2021. LED Lenses. URL: https://www.auer-lighting.com/en/products/lenses/led-lense (Last accessed: 14.03.2021).

2. Autodesk. 2016. Missing the Mark: How to avoid or camouflage marks in injection-molded parts. Resource Center. URL: https://damassets.autodesk.net/content/ dam/autodesk/www/mech-eng-ressource-center/caeanalyst/assets/fy17-mold-engineer-sink-marks-report-en.pdf (Last accessed: 15.03.2021)

3. Bozzelli J. Why Multi-Cavity Molds Fill Unevenly. URL: https://www.ptonline.com/articles/whymulti-cavity-molds-fill-unevenly (Accessed 09 May 2021).

4. Ecomolding. 2019. What causes scratches in injection molding products. URL: https://www.ecomolding. com/scratches/ (Last accessed: 09.05.2021).

5. Merriam-Webster. 2021. Injection moulding. URL: $\quad$ https://www.merriam-webster.com/dictionary/ injection\%20molding (Last accessed: 27.02.2021).

6. ONEX Machinery. 2021. What Are the Important Parameters of the Injection Moulding Process? URL: https://onexlimited.com $/ \% \mathrm{e} 2 \% 85 \% \mathrm{~b} 0$-what-are-the- 
important-parameters-of-the-injection-molding-process/

(Last accessed: 17.03.2021).

7. Pačaiová H., Andrejiová M., Balažiková M. et al. Methodology for Complex Efficiency Evaluation of Machinery Safety Measures in a Production Organization. Appl. Sci. 2021. 11. P. 453. doi: 10.3390/app11010453.

8. Pačaiová H., Ižaríková G. Base Principles and Practices for Implementation of Total Productive Maintenance in Automotive Industry. Quality Innovation Prosperity. 2019. 23 (1). P. 45-59. doi: 10.12776/qip.v23i1.1203.

9. Plainis S., Murray I. J., Pallikaris I. G. Road traffic casualties: understanding the night-time death toll. Injury prevention: Journal of the International Society for Child and Adolescent. 2006. Vol. 12(2). P. 125-128. URL: https://www.ncbi.nlm.nih.gov/pmc/articles/PMC2564438/ (Last accessed: 14.03.2021).

10. Plasty G. Konštrukcia a výroba šošoviek pre LED svetlomety $\mathrm{z}$ plastu namiesot skla. URL: https://www.plasticportal.sk/sk/konstrukcia-a-vyrobasosoviek-pre-led-svetlomety-z-plastu-namiestoskla.html/c/6647/ (Accessed 09 May 2021).

11. Resinex. 2021. Mould Parts Function. URL: https://www.sinomould.com/Mould-part-function.html (Last accessed: 15.09.2021).
12. Resinex. 2021. PMMA Altuglas. URL: https://www.resinex.cz/produkty/altuglas.html (Last accessed: 29.04.2021).

13. Rosato Dominick V., Rosato Donald V., Rosato Matthew V. Plastic Product Material and Process Selection Handbook. doi: 10.1016/B978-1-85617-431-2.X5000-2.

14. Silver Optics. 2020. About us. URL: http://www. opticslenschina.com/ (Last accessed: 15.09.2021).

15. Simcon. 2020. Project OptiSys: Plastic instead of glass - we collaborated with partners including KraussMaffei, Hella and Fraunhofer, to create new multilayered lenses for LED headlights. URL: https://www.simcon.com/project-optisys-plastic-instead-ofglass (Last accessed: 05.09.2021).

16. Xie Lei, Shen Longjiang, Jiang Bingyan. Modelling and Simulation for Micro Injection Molding Process. doi: 10.5772/16283.

17. Yadav A. Subject study of operation and maintenance of all electric injection moulding machine. URL: https://www.slideshare.net/anymona1991/seminaron-all-electrical-injection-moulding-machine-main (Last accessed: 17.03.2021). 